\title{
EGG TRANSFER IN THE COW: FACTORS AFFECTING PREGNANCY AND TWINNING RATES FOLLOWING BILATERAL TRANSFERS
}

\author{
J. M. SREENAN, D. BEEHAN AND P. MULVEHILL \\ The Agricultural Institute, Belclare, Tuam, Co. Galway, Ireland
}

(Received 12th November 1974)

\begin{abstract}
Summary. A total of 112 heifers was used in an egg transfer study to examine some of the factors affecting egg survival and twinning rates following bilateral transfers. Seventy-two recipient heifers were involved and pregnancy rates of $82.0 \%, 66.7 \%$ and $61.5 \%$ were recorded for recipients in oestrus on the same day as (Day 0$), 1$ day before (Day +1 ) and 1 day after (Day -1) the donor respectively. Short-term (10-day) intravaginal progesterone, or intramuscular prostaglandin treatments for synchronization of oestrus in recipient animals did not depress pregnancy rate following egg transfer. One egg was transferred to each uterine horn and twinning rates of $55.6 \%, 44.4 \%$ and $20.0 \%$ were recorded for transfers on Days $0,+1$ and -1 , respectively. Of the recipients becoming pregnant following transfers on Day $0,74 \cdot 1 \%$ had twins. Embryo survival was higher $(69.2 \%)$ in the uterine horn adjacent to the ovary containing the CL than in the opposite horn $(30.8 \%)$.

The storage period in vitro in TC $199\left(37 \pm 1^{\circ} \mathrm{C}\right)$ affected subsequent egg survival rates following transfer, with fewer eggs surviving the longer storage periods. The $\mathrm{pH}$ of the medium used for egg collection and storage did not affect the pregnancy rate between $\mathrm{pH}$ values of 7.0 to $8 \cdot 6$. Day of transfer (Days 3 to 7 ) did not seem to affect the pregnancy rate.

The high pregnancy and twinning rates already reported following closely synchronized transfers were confirmed.
\end{abstract}

\section{INTRODUCTION}

The frequency of twin births among cattle has been generally reported to be within the range of 1 to $5 \%$ and varies according to breed, age and environment (Scanlon, Gordon \& Sreenan, 1974). Data on the incidence of twin ovulations are less well documented and therefore it is more difficult to estimate the level of embryonic mortality. Following the use of PMSG for ovarian stimulation, Gordon, Williams \& Edwards (1962) reported a higher incidence of embryo loss when two ovulations occurred from one ovary than when one ovulation occurred from each. Following a series of egg transfer experiments, Rowson, Lawson \& Moor (1971) showed that twin pregnancy in the cow could be sustained by a single CL provided that one fertilized egg was transferred to each uterine horn. 
From eighteen transfers, eleven heifers became pregnant and eight of these either produced normal twin calves or had viable fetuses at slaughter at 90 days.

The aim of the present studies was to examine some of the factors affecting pregnancy and twinning rates in beef heifers following the transfer of one fertilized egg to each uterine horn.

\section{MATERIALS AND METHODS}

A total of 112 maiden heifers was used. Of these, forty were donor animals and seventy-two were recipients. The breeds involved were mainly Hereford and Aberdeen Angus crosses with a mean weight at transfer of $320 \mathrm{~kg}$.

\section{Donor heifers}

Superovulation in donor heifers was induced by the intramuscular administration of PMSG (Folligon: Intervet). Two groups were treated as follows.

Group 1. Heifers were injected with 1500 or 2500 i.u. PMSG during the follicular phase of the oestrous cycle (Day 15 or 16). Those showing an oestrous response were injected intravenously with 2000 i.u. HCG (Chorulon: Intervet) between 2 and $6 \mathrm{hr}$ after the start of oestrus, while heifers not coming into oestrus were similarly injected at 12.00 hours on Day 21 .

Group 2. Heifers were injected with 1500 or 2500 i.u. PMSG during the midluteal phase (Days 8 to 12) of the oestrous cycle. Beginning 2 days after PMSG, each animal was injected intramuscularly with a total of 900 or $1000 \mu \mathrm{g}$ prostaglandin analogue (I.C.I. 79,939 or 80,996) over 2 days. Following treatment, all donors were checked for oestrus with the aid of vasectomized teaser bulls fitted with chin-ball marking harnesses. Inspections were carried out routinely at $08.00,12.00$ and 18.00 hours. Between 18.00 and 08.00 hours, vasectomized marker bulls were kept with the heifers. Donors exhibiting standing oestrus were naturally mated approximately $6 \mathrm{hr}$ after the start of oestrus and were then artificially inseminated twice, at 8 - and $16-\mathrm{hr}$ intervals. Donors not detected in standing oestrus were inseminated two or three times over the period of expected oestrus. All inseminations were carried out with frozen-thawed semen (approximately $30 \times 10^{6}$ spermatozoa/straw).

\section{Recipient heifers}

Recipient heifers were either untreated (control) cyclic heifers selected on the basis of having been detected in oestrus within 1 day of the occurrence of oestrus in the donor, or were artificially synchronized as follows: (1) progesterone impregnated $(3.0 \mathrm{~g})$ sponge pessaries were inserted into the vagina for a 10-day period. On the day of insertion, each heifer was injected with a combination of progesterone $(250 \mathrm{mg})$ and oestradiol benzoate $(7.5 \mathrm{mg})$. After removal of the pessary, the heifers were checked for standing oestrus and were used as recipients when the degree of synchronization with the donor was exact (Day 0 ) or out of phase by \pm 1 day; (2) a second group of heifers received $500 \mu \mathrm{g}$ I.C.I. 80,996 intramuscularly during the luteal phase (Days 5 to 15) of the oestrous cycle. Heifers were then checked for standing oestrus and were used when synchronization was exact (Day 0) or \pm 1 day out of phase. Except for one recipient treated with 
prostaglandin, fertilized eggs were transferred to each recipient from the same donor and on the same day.

\section{Egg recovery}

Egg recovery from donor animals was carried out by surgical means. Heifers were anaesthetized with thiopentone sodium, followed by closed circuit anaesthesia with fluothane and oxygen. The ovaries and uterine horns were exposed through a mid-line incision. A polythene tube was inserted approximately $25 \mathrm{~mm}$ into the oviducts, and the uterine horns were flushed, the medium passing through the oviducts into sterile glass collection dishes. The flushings were examined under a binocular microscope in a temperature-controlled cabinet at $35 \pm 2{ }^{\circ} \mathrm{C}$. When located, eggs for transfer were immediately placed in fresh medium and held in covered dishes (at $37 \pm 1^{\circ} \mathrm{C}$ ) until transfer.

\section{Flushing medium}

Two media were used for egg collection and storage before transfer; TC 199 (B) was based on Earle's basic salt solution and buffered with sodium bicarbonate; TC 199 (H) was based on Hanks' basic salt solution and was buffered with Hepes buffer. No antibiotics or other additives were used with these media. Measurements of $\mathrm{pH}$ were carried out on the collection and storage media at regular intervals and the change recorded for the time intervals involved.

Storage periods of eggs

After recovery, eggs for transfer were stored in fresh aliquots of collection medium in sealed dishes for periods ranging from 40 to $480 \mathrm{~min}$.

\section{Degree of synchronization of oestrus}

Eggs were transferred to recipient heifers that exhibited standing oestrus either on the same day or approximately $24 \mathrm{hr}$ out of phase with the oestrus of the donor.

\section{Egg transfers}

Egg transfers to recipient heifers were carried out by surgical procedures. Anaesthesia was induced by thiopentone sodium, followed by closed circuit anaesthesia with fluothane and oxygen. The uterine horns were exposed through a mid-line incision. Both ovaries were checked for the presence of a CL and one fertilized egg was transferred to each uterine horn. Each egg was drawn into a sterile Pasteur pipette connected to a $1-\mathrm{ml}$ syringe. Approximately $0.20 \mathrm{ml}$ medium was drawn into the pipette with the egg. Transfer was carried out by first puncturing the uterine wall with a sterile needle and then introducing the Pasteur pipette into the uterine lumen. The pipette was introduced towards the oviduct and the eggs were deposited between 25 and $50 \mathrm{~mm}$ from the uterotubal junction. The collection and transfer procedures were carried out in a temperature of 25 to $30^{\circ} \mathrm{C}$. Only fertilized eggs that were regarded as morphologically normal were transferred.

Following transfers, all recipient heifers were checked for return to oestrus with the use of vasectomized marker bulls. To establish positive pregnancy 
diagnosis and embryo or fetal normality, fifty-five recipients were slaughtered between 27 and 117 days. The reproductive tracts were recovered, the number and location of embryos or fetuses were recorded, and the fetuses were measured. A number of recipients were allowed to calve and positive pregnancy diagnosis was established by palpation after 90 days. To avoid possible damage, no attempt was made to establish the number and location of the fetuses in these heifers.

\section{RESULTS}

The pregnancy rate following bilateral egg transfers to all recipients is shown in Table 1. The highest pregnancy rate was obtained in the group of recipients exactly synchronized with the donor animals. When recipients were out of

Table 1. Pregnancy rates following bilateral egg transfers in cows

\begin{tabular}{ccrc}
\hline $\begin{array}{c}\text { Degree } \\
\text { of } \\
\text { synchronization } \\
\text { (days) }\end{array}$ & $\begin{array}{c}\text { No. } \\
\text { of } \\
\text { recipients }\end{array}$ & $\begin{array}{c}\text { No. } \\
\text { pregnant }\end{array}$ & $\%$ Pregnant \\
\hline 0 & 50 & 41 & $82 \cdot 0$ \\
-1 & 13 & 8 & $61 \cdot 5$ \\
+1 & 9 & 6 & $66 \cdot 7$ \\
Total & 72 & 55 & $76 \cdot 4$ \\
\hline
\end{tabular}

phase by I day, pregnancy rates were approximately $20 \%$ lower but this difference was not significant $\left(\chi^{2}=2 \cdot 8\right.$, d.f. $\left.=2, P>0 \cdot 01\right)$. Data on embryo survival and twinning rates in recipients slaughtered between 27 and 117 days are presented in Table 2 . The heifers in the closely synchronized recipient group had a higher proportion of viable embryos at slaughter than those in the \pm 1 day groups, but again the difference was not significant $\left(\chi^{2}=4 \cdot 0\right.$, d.f. $\left.=2, P>0 \cdot 10\right)$. The proportion of all recipients and those pregnant that had viable twin fetuses at slaughter is also shown in Table 2. The effect of method and degree of synchronization on pregnancy rate is shown in Table 3. Following both synchronization treatments, all heifers (eight) that were out of phase by 1 day became pregnant. By contrast, in the control group, only $6 / 14$ recipients ( \pm 1 day) became pregnant. Data on egg survival in slaughtered heifers are presented in Table 4. While egg survival rates were similar for all exactly synchronized recipients (Day 0 ), the survival rates in the artificially synchronized recipients $( \pm 1$ day) out of phase were higher than controls, though the number involved was too small to draw conclusions.

Single pregnancies were recorded for thirteen recipients in the slaughtered animals and embryo survival relative to the site of the CL is shown in Table 5. A higher $\left(\chi^{2}=3.8\right.$, d.f. $\left.=1, P<0.01\right)$ proportion of eggs developed into viable embryos or fetuses when transferred to the uterine horn adjacent to the ovary containing the CL. 
Table 2. Egg survival and twinning rates at slaughter following bilateral transfers in cows

\begin{tabular}{ccccccc}
\hline \multirow{2}{*}{$\begin{array}{c}\text { Degree } \\
\text { of }\end{array}$} & $\begin{array}{c}\text { No. of } \\
\text { synchronization } \\
\text { (days) }\end{array}$ & $\begin{array}{c}\text { Nocipients } \\
\text { reglled }\end{array}$ & $\begin{array}{c}\text { eggs } \\
\text { transferred }\end{array}$ & $\begin{array}{c}\text { \% Embryo } \\
\text { survival }\end{array}$ & $\begin{array}{c}\text { Cows with twins }(\%) \\
\text { recipients }\end{array}$ & $\begin{array}{c}\text { Pregnant } \\
\text { recipients }\end{array}$ \\
\hline 0 & 36 & 72 & $65 \cdot 3$ & $55 \cdot 6$ & $74 \cdot 1$ \\
-1 & 10 & 20 & 40.0 & $20 \cdot 0$ & $33 \cdot 3$ \\
+1 & 9 & 18 & $55 \cdot 6$ & $44 \cdot 4$ & 66.6 \\
\hline
\end{tabular}

Table 3. Effect of method and degree of synchronization on pregnancy rate following bilateral egg transfer in cows

\begin{tabular}{|c|c|c|c|c|c|c|}
\hline \multirow{2}{*}{$\begin{array}{c}\text { Degree } \\
\text { of } \\
\text { synchronization } \\
\text { (days) }\end{array}$} & \multicolumn{2}{|c|}{ Control } & \multicolumn{2}{|c|}{ Progesterone } & \multicolumn{2}{|c|}{ Prostaglandin } \\
\hline & $\begin{array}{l}\text { No. of } \\
\text { recipients }\end{array}$ & $\underset{\text { pregnant }}{\text { No. }}$ & $\begin{array}{c}\text { No. of } \\
\text { recipients }\end{array}$ & $\underset{\text { pregnant }}{\text { No. }}$ & $\begin{array}{l}\text { Noo. of } \\
\text { recipients }\end{array}$ & $\begin{array}{c}\text { No. } \\
\text { pregnant }\end{array}$ \\
\hline $\begin{array}{r}-1 \\
0 \\
+1\end{array}$ & $\begin{array}{r}10 \\
12 \\
4\end{array}$ & $\begin{array}{r}5 \\
10 \\
1\end{array}$ & $\begin{array}{r}1 \\
10 \\
2\end{array}$ & $\begin{array}{l}1 \\
7 \\
2\end{array}$ & $\begin{array}{l}2 \\
8 \\
3\end{array}$ & $\begin{array}{l}2 \\
7 \\
3\end{array}$ \\
\hline Total & \multicolumn{2}{|c|}{$61.5 \%$} & \multicolumn{2}{|c|}{$76.9 \%$} & \multicolumn{2}{|c|}{$92.3 \%$} \\
\hline
\end{tabular}

Table 4. Effect of method and degree of synchronization on egg survival in heifers slaughtered between 27 and 117 days

\begin{tabular}{|c|c|c|c|c|c|c|}
\hline \multirow{2}{*}{$\begin{array}{c}\text { Degree } \\
\text { of } \\
\text { synchronization } \\
\text { (days) }\end{array}$} & \multicolumn{2}{|c|}{ Control } & \multicolumn{2}{|c|}{ Progesterone } & \multicolumn{2}{|c|}{ Prostaglandin } \\
\hline & $\begin{array}{c}\text { No. of } \\
\text { eggs }\end{array}$ & $\begin{array}{c}\text { No. } \\
\text { surviving }\end{array}$ & $\begin{array}{c}\text { No. of } \\
\text { eggs }\end{array}$ & $\begin{array}{c}\text { No. } \\
\text { surviving }\end{array}$ & $\begin{array}{c}\text { No. of } \\
\text { eggs }\end{array}$ & $\underset{\text { Norviving }}{\text { No. }}$ \\
\hline $\begin{array}{r}-1 \\
0 \\
+1\end{array}$ & $\begin{array}{r}14 \\
24 \\
8\end{array}$ & $\begin{array}{r}4 \\
17 \\
2\end{array}$ & $\begin{array}{r}2 \\
18 \\
4\end{array}$ & $\begin{array}{r}1 \\
11 \\
3\end{array}$ & $\begin{array}{r}4 \\
14 \\
6\end{array}$ & $\begin{array}{r}3 \\
10 \\
5\end{array}$ \\
\hline Total & \multicolumn{2}{|c|}{$50.0 \%$} & 24 & $62.5 \%$ & \multicolumn{2}{|c|}{$75.0 \%$} \\
\hline
\end{tabular}

Table 5. Embryo survival in single pregnancies relative to site of corpus luteum following twin egg transfers in cows

\begin{tabular}{lcc}
\hline & $\begin{array}{c}\text { Ipsilateral } \\
\text { to } C L\end{array}$ & $\begin{array}{c}\text { Contralateral } \\
\text { to } C L\end{array}$ \\
\hline $\begin{array}{l}\text { No. of eggs transferred } \\
\text { No. of embryos at slaughter }\end{array}$ & 13 & 13 \\
$\%$ Survival & 9 & 4 \\
& 69.2 & $30 \cdot 8$ \\
\hline
\end{tabular}


twenty-six were held in TC 199 (B) and twenty-two in TC 199 (H), ten eggs from each medium developed into viable embryos or fetuses following transfer to recipients.

\section{Day of egg transfer}

Eggs were transferred between 3 and 7 days from oestrus and the data in Table 8 do not indicate any effect of day of transfer on subsequent pregnancy rate. Of the seventy-two recipients in this trial, seventeen failed to become pregnant following transfer and most of these $(82.3 \%$ ) had normal cycle lengths (18 to 25 days from the oestrus before transfer). One heifer had a cycle length of 10 days and two had cycle lengths between 38 and 45 days.

Table 8. Effect of day of transfer on pregnancy rate following bilateral transfer of cow eggs

\begin{tabular}{|c|c|c|c|c|c|c|c|c|}
\hline \multirow{3}{*}{$\begin{array}{l}\text { Degree of } \\
\text { synchronization } \\
(\text { days })\end{array}$} & \multicolumn{8}{|c|}{ Day of transfer } \\
\hline & \multicolumn{2}{|c|}{3} & \multicolumn{2}{|c|}{5} & \multicolumn{2}{|c|}{6} & \multicolumn{2}{|c|}{7} \\
\hline & $\begin{array}{c}\text { No. of } \\
\text { recipients }\end{array}$ & $\underset{\text { pregnant }}{\text { No. }}$ & $\begin{array}{c}\text { No. of } \\
\text { recipients }\end{array}$ & $\underset{\text { pregnant }}{\text { No. }}$ & $\begin{array}{l}\text { No. of } \\
\text { recipients }\end{array}$ & $\underset{\text { pregnant }}{\text { No. }}$ & $\begin{array}{l}\text { No. of } \\
\text { recipients }\end{array}$ & $\underset{\text { pregnant }}{\text { No. }}$ \\
\hline $\begin{array}{r}0 \\
-1 \\
+1\end{array}$ & $\begin{array}{l}3 \\
2\end{array}$ & $\begin{array}{l}3 \\
1\end{array}$ & $\begin{array}{l}7 \\
2 \\
1\end{array}$ & $\begin{array}{l}6 \\
1 \\
1\end{array}$ & $\begin{array}{r}28 \\
6 \\
7\end{array}$ & $\begin{array}{r}20 \\
4 \\
5\end{array}$ & $\begin{array}{r}12 \\
3 \\
1\end{array}$ & $\begin{array}{r}12 \\
2 \\
0\end{array}$ \\
\hline Total & \multicolumn{2}{|c|}{${ }^{5} 80.0 \%$} & \multicolumn{2}{|c|}{${ }_{80.0 \%} 8$} & \multicolumn{2}{|c|}{$41{ }_{70.7 \%}{ }^{29}$} & \multicolumn{2}{|c|}{${ }_{87.5 \%}^{14}$} \\
\hline
\end{tabular}

\section{DISGUSSION}

The results presented confirm earlier reports of high pregnancy rates following surgical egg transfer in cattle (Rowson, Moor \& Lawson, 1969; Rowson et al., 1971; Rowson, Lawson, Moor \& Baker, 1972; Sreenan \& Beehan, 1974). These authors report pregnancy rates of 91 to $91.7 \%$ following transfers where donors and recipients were closely synchronized. In this study, the over-all pregnancy rate for closely sychronized transfers was $82 \%$ and was based on fifty transfer attempts. The pregnancy rate of recipients out of phase by 1 day was lower, though not significantly, than synchronized transfers and no difference was recorded between recipients in oestrus before the donor (Day +1$)$ and those in oestrus after the donor (Day -1). This is in agreement with the results of Rowson et al. (1972) who reported lower pregnancy rates of recipients out of phase by 1 day but no differential effect of day $( \pm)$. The indications are that, in sheep, recipients coming into oestrus 1 day after the donor have a higher pregnancy rate than those in oestrus 1 day before the donor (Hunter, Adams \& Rowson, 1955; Rowson \& Moor, 1966), and similar data have been reported for the pig (Webel, Peters \& Anderson, 1970).

The egg survival and twinning rates presented here are similar to those previously reported for a smaller group of recipients (Sreenan \& Beehan, 1974) and agree with the data of Rowson et al. (1972) who recorded a twinning rate of 
$78.6 \%$ for pregnant heifers following close synchronization with the donors. In this study, a twinning rate of $74 \cdot 1 \%$ was recorded for closely synchronized recipients (Day 0 ) following bilateral transfers.

The data presented on pregnancy rate and egg survival following egg transfer to artificially synchronized recipients are consistent with the pregnancy rates reported for similar treatments following breeding at the controlled oestrus. After similar progesterone treatment of heifers, Sreenan \& Mulvehill (1975) reported 'controlled-oestrus' conception rates of 50 to $83.3 \%$ following set-time artificial insemination. Treatments with prostaglandin $F_{2 \alpha}$ have resulted in a pregnancy rate similar to that of control animals (see review by Lauderdale, 1973). No comparable data are available in the literature on pregnancy rate following egg transfer to artificially synchronized heifers.

It is clearly possible to achieve a high rate of twinning in cattle after transfer of one fertilized egg to each uterine horn of either naturally cyclic or artificially synchronized recipients. When two fertilized eggs were transferred to one uterine horn, Rowson et al. (1972) noted that egg survival was reduced leading to a much lower twinning rate and they suggested that, because transuterine migration rarely occurs in cattle, embryonic death results simply from overcrowding in the one horn. In this study, embryos survived at a higher rate $(69.2 \%)$ in the uterine horn adjacent to the CL than in the contralateral horn $(30.8 \%)$. This difference was significant $(P<0.01)$ and indicates a possible local relationship between the CL and the site of embryo transfer, but this requires further study involving a series of single egg transfers to the horns ipsilateral and contralateral to the ovary containing the CL.

The collection and storage media were adequate whether based on Hanks' basic salt solution and buffered with Hepes buffer (TC $199 \mathrm{H}$ ) or on Earle's basic salt solution and buffered with sodium bicarbonate (TC 199 B). It did seem, however, that these media were not satisfactory when the storage period was over $2 \mathrm{hr}$. Eggs stored from 121 to $480 \mathrm{~min}$ had a significantly lower $(P<0.01)$ survival rate than eggs stored for 40 to $120 \mathrm{~min}$. The $\mathrm{pH}$ of both media was measured at regular intervals during transfers and, in particular, aliquots in which eggs were stored were checked for $\mathrm{pH}$ immediately the eggs were removed. Medium TC 199 (B) was normally at a pH of 8.0 after storage for $1 \mathrm{hr}$ and $8.5 \pm 0.1$ after $3 \mathrm{hr}$, while TC $199(\mathrm{H})$ changed from $7 \cdot 0$ to $7 \cdot 3 \pm 0 \cdot 1$ after approximately $400 \mathrm{~min}$. From the egg survival data following transfers, it is clear that cattle eggs can withstand a $\mathrm{pH}$ change in the storage medium from 7.0 to 8.6 without any adverse effect on embryo survival. Following the longer storage periods, egg survival was similar in both media. This indicates that some modification of the medium may be necessary for longer storage periods at $37 \pm 1^{\circ} \mathrm{C}$. Rowson et al. (1972), however, found that storage of fertilized eggs in TC 199 at $37^{\circ} \mathrm{C}$ from 100 to $300 \mathrm{~min}$ did not result in a lowering of pregnancy rate in the later storage periods, but the number of eggs in the later storage period (200 to $300 \mathrm{~min}$ ) was smaller than in this communication.

There is no indication from the present studies that the day of transfer affected pregnancy rate or egg survival rate following transfer but there were only five recipients on Day 3 so it is difficult to draw any definite conclusions until more data are produced on early stage transfers. 
Of the seventeen recipients that failed to become pregnant, a small number had extended cycle lengths but these may have been animals in which oestrus (silent oestrus) was not detected. The data presented confirm that high pregnancy and twinning rates may be obtained in cattle following the surgical transfer of one fertilized egg to each uterine horn. Another approach to twinning would be that already suggested by Rowson et al. (1971), i.e. to transfer one fertilized egg to recipients already inseminated and to ensure that the transferred egg would be placed in the uterine horn contralateral to the ovary containing the CL.

\section{ACKNOWLEDGMENTS}

We thank Mr M. J. Cooper, ICI Ltd, for the prostaglandin analogues (I.C.I. 79,939 and I.C.I. 80,996), Mr A. McDonagh for excellent technical assistance and $\mathrm{Mr}$ G. Morris and Mr P. Creaven for help at all stages of this work.

\section{REFERENCES}

Gordon, I., Williams, G. L. \& Edwards, J. (1962) The use of PMS (serum gonadotrophin) in the induction of twin pregnancy in the cow. $\mathcal{F}$. agric. Sci., Camb. 59, 143-198.

Hunter, G. L., Adams, G. E. \& Rowson, L. E. A. (1955) Interbreed ovum transfer in sheep. F. agric. Sci., Camb. 46, 143-149.

Lauderdale, J. W. (1973) Fertility and sperm transport following prostaglandin or progestogen treatment of cattle. Colloq. Inst. natn Sante Rech. méd. 26, 499-509.

Rowson, L. E. A., Lawson, R. A. S. \& Moor, R. M. (1971) Production of twins in cattle by egg transfer. F. Reprod. Fert. 25, 261-268.

Rowson, L. E. A., Lawson, R. A. S., Moor, R. M. \& Baker, A. A. (1972) Egg transfer in the cow: synchronization requirements. F. Reprod. Fert. 28, 427-432.

Rowson, L. E. A. \& MooR, R. M. (1966) Embryo transfer in the sheep: the significance of synchronization of oestrus in the donor and recipient animal. 7. Reprod. Fert. 11, 207-212.

Rowson, L. E. A., Moor, R. M. \& LAwson, R. A. S. (1969) Fertility following egg transfer in the cow, effect of method, medium and synchronization of oestrus. J. Reprod. Fert. 18, 517-523.

Scanlon, P. F., Gordon, I. \& SReenan, J. (1974) Multiple ovulations, multiple pregnancies and multiple births in Irish cattle. F. Ir. Dept Agric. Fish. 70, 2-18.

SREENAN, J. \& BEEHAN, D. (1974) Egg transfer in the cow: pregnancy rate and egg survival. f. Reprod. Fert. 41, 497-499.

SReenan, J. \& Mulvehill, P. (1975) The application of long- and short-term progestagen treatments for oestrous cycle control in heifers. $\mathcal{F}$. Reprod. Fert. (in press).

Webel, S. A., Peters, J. B. \& Anderson, L. L. (1970) Synchronous and asynchronous transfer of embryos in the pig. F. Anim. Sci. 30, 565-568. 